\title{
Peran Lirik Lagu Dalam Meningkatkan Komunikasi Verbal Pada Anak Austisitk di Sekolah Bina Anggita Yogykarta
}

\author{
Zefanya Lintang Nugrahaningsih \\ Program Studi Pasca Sarjana Institut Seni Indonesia Yogyakarta, Pengkajian dan Penciptaaan Seni \\ PPS Institut Seni Indonesia Yogyakarta
}

\begin{abstract}
This study aims to improve verbal communication in autistic children by using lyrics on children's songs. Due to the expected increase in verbal skills for autistic children. This research is a qualitative research with case study approach and supported by literature study to provide complete information about this research. There are 4 stages: Preliminary Stage, Field Work Stage, and Data Collection Stages. Research subjects were autistic students in Bina Anggita Yogyakarta school amounted to 5 students. Data collection used in this research is using observation guideline and previous researcher do literature study first. Data analysis in this study using descriptive qualitative. The results of this study indicate that the role of lyrics in the song Balonku and Pelangi-Pelangi can improve the verbal language of autistic children. Autistic children are stimulated to sing together when involved to sing together..
\end{abstract}

Keywords: Lyrics, Verbal, Autistic.

\begin{abstract}
Abstrak
Penelitian ini bertujuan untuk meningkatkan komunikasi verbal pada anak autistik dengan menggunakan lirik pada lagu anak-anak, karena diharapkan dapat meningkatnya kemampuan bekomunikasi secara verbal bagi anak autistik. Penelitian ini merupakan penelitian kualitatif dengan pendekatan studi kasus dan didukung dengan studi pustaka guna memberikan informasi-informasi secara lengkap tentang penelitian ini. Ada 4 tahapan yaitu: Tahapan pra-lapangan, Tahap Pekerjaan lapangan, dan Tahapan Hasil Pengumpulan Data. Subjek penelitian adalah siswa autistik di sekolah Bina Anggita Yogyakarta berjumlah 5 siswa. Pengumpulan data yang digunakan dalam penelitian ini adalah menggunakan pedoman observasi dan sebelumnya peneliti melakukan studi pustaka terlebih dahulu. Analisis data dalam penelitian ini menggunakan deskriptif kualitatif. Hasil penelitian ini menunjukkan bahwa peran lirik dalam lagu Balonku dan Pelangi-Pelangi dapat meningkatkan bahasa verbal anak autistik. Anak autistik terstimulus untuk menyanyi bersama saat dilibatkan untuk benyanyi bersama-sama.
\end{abstract}

Kata kunci: Lirik, Verbal, Autistik

\section{Pengantar}

Pada dasarnya manusia mengalami perkembangan dimulai dari balita, anakanak, remaja, dewasa, dan lansia. Masa anakanak merupakan suatu fenomena yang pasti dialami oleh setiap manusia pada rentan kehidupan sebagai proses dari perkembangan. Masa anak-anak adalah salah satu fase penting dalam kehidupan manusia untuk membentuk sebuah kepribadian didalam diri tiap-tiap individu dan sebagai titik awal pada kehidupan manusia untuk menuju sebuah pribadi yang utuh. Tidak semua anak-anak menjalani perkembangan yang sempurna, ada beberapa anak yang memiliki keterbatasan baik secara fisik, mental maupun keterbatasan dalam kemampuan interaksi 
sosial atau emosi. Salah satu perkembangan yang terlihat sekali perbedaanya dalam hal komunikasi, interaksi sosial, bahasa, pikiran dan prilaku dari anak normal pada umumnya adalah perkembangan yang terjadi pada anak autistik. Salah satu contoh gejala yang membedakannya berdasarkan DSM V adalah perkembangan anak berjalan lebih lambat dibandingkan dengan anak seusianya (http://www.otsuka.co.id/id/healthinfo/detail). Anak autistik mengalami gangguan dalam perkembangan yang sudah dapat dideteksi sejak masa balita (neurodevelopmental) dan akan berlanjut hingga sepanjang rentang kehidupan.

Menurut The Association for Autistic Children, Autism dipahami sebagai gangguan perkembangan neurobiologis yang berat sehingga gangguan tersebut mempengaruhi bagaimana anak belajar, berkomunikasi, keberadaan dalam lingkungan dan hubungan dengan orang lain (hubungan sosial). Gangguan perkembangan yang terjadi pada anak dengan autistik bisa disebabkan dari beberapa faktor seperti faktor genetika dan pengaruh dari lingkungan. Belum ada data statistik yang pasti tentang jumlah pengidap anak autistik di Indonesia namun data menurut dr Widodo Judarwanto, jumlah penderita autis di Indonesia ditahun 2015 diperkirakan satu per 250 anak mengalami gangguan spectrum autisme. Tahun 2015 diperkirakan terdapat kurang lebih 12.800 anak pengidap autisme dan 134.000 pengidap spectrum autisme di Indonesia (http://www.klinikautis.com). Sehingga banyak metode pembelajaran dan terapy dikembangkan untuk meningkatkan dan mengembangkan kemampuan anak autistik. Salah satunya adalah penggunaan musik untuk pengembangan kemampuan bahasa, pengembangan kemampuan sensori motorik, pengembangan konsep kognitif, dan pengembangan kemampuan sosioemosional (Djohan, 2006).
Salah satu penelitian terdahulu oleh Milyartini, (2010) mengenai peran musik terhadap perkembangan anak dengan kebutuhan khusus, mengemukakan bahwa musik dapat berperan penting untuk meningkatkan multi kecerdasan pada ABK (Anak Berkebutuhan Khusus). Menurutnya proses pemanfaatan musik dapat dilakukan melalui aktivitas menyimak, aktivitas memproduksi/memainkan musik dan berkarya musik yang terintegrasi dengan gerak. Masing-masing keterbatasan (mental, fisik, atau sosial) membutuhkan strategi pemanfaatan musik yang khas. Aktivitas bermusik memungkinkan ABK memperoleh kepercayaan diri, harga diri dan motivasi untuk hidup lebih baik.

Dari pernyataan tersebut dapat ditarik kesimpulan bahwa musik dapat menstimulasi intergrasi motorik, sosial, kemampuan kognitif, komunikasi, dan perkembangan emosi pada $A B K$, serta setiap individu ABK memiliki kebutuhan treatment dalam musik yang berbeda-beda dan harus mengaplikasikannya secara tepat, begitu juga halnya dengan pengidap autistime. Nurwinda, (2014) mengemukakan bahwa musik dapat, membantu perkembangan bahasa verbal atau nonverbal anak ABK seperti mengikuti lirik lagu saat musik diperdengarkan dengan cara memutarkan lagu anak-anak lalu terapis dan anak autistik ikut bernyanyi bersama. Stimulasi musik sangat mempengaruhi fungsi otak dan mampu menyeimbangkan fungsi otak kanan dan otak kiri, yang secara tidak langsung menyeimbangkan perkembangan aspek intelektual dan emosional. Menurut Kanner, (1971) dalam penelitiannya follow-up study of eleven autistic children originally reported in 1943 mengatakan bahwa anak yang pengidap autisme secara konsisten menunjukan kepekaan yang luar biasa dan memiliki perhatian terhadap musik.

Pada kenyataanyan, banyak literatur tentang autisme melaporkan bahwa anak yang tidak merespon dengan cara berbicara, namun 
pada saat diperdengarkan musik anak autistik akan merespon dengan cara nonverbal seperti mengikuti potongan lirik lagu yang sedang didengarkan. Alice-Ann \& Tammy, (1999) musik juga dapat memberikan efek bagi penyandang autisme dalam kemampuan mengingat benda yang tidak terlihat. Alice-Ann \& Tammy, (1999) mencatat bahwa meskipun Temple Grandin didiagnosis dengan autisme sejak ia kecil dia bisa mendapatkan gelar profesor dalam ilmu hewan dan dikenal sebagai profesor ilmu hewan di Colorado State University. Atribut kesuksesan Temple Grandin adalah sebagian besar karena musik, dan ia menyatakan bahwa melodi adalah satu-satunya hal yang dapat ia ingat. Berdasarkan studi pendahuluan yang penulis lakukan saat mengikuti seminar yang diadakan oleh MTCI (Music Therapy Center Indonesia) dalam acara Music Therapy Conference 2017 (30 Maret- 1 April 2017) ditemukan fakta bahwa anak berkebutuhan khusus seperti anak pengidap autisme dapat merespon musik dengan cara menggerakkan tangan atau kakinya. Gerakan-gerakannya berusaha untuk menyesuaikan tempo musik yang ia dengarkan (Anette, 2017)

Serta Anette, (2017) memaparkan bahwa anak autistik akan tertarik dan merespon jika suatu instruksi dari terapis dinyanyikan, seperti instruksi mengikuti gerakan-gerakan dari sang terapis. Bila instruksi tidak dinyanyikan anak autistik tidak akan merespon instruksi tersebut. Hal tersebut dapat terjadi dikarenakan bernyanyi dan bermain musik adalah salah satu hal yang menyenangkan dan menarik perhatian bagi anak autistik. Anak autistik juga dapat merespons terapis saat terapis berinteraksi dengan cara mengajak anak autistik bermain musik, dan memanipulasi musik untuk meningkatkan kognitif anak autistik seperti contoh yang diberikan oleh terapis. Menutur Saphira Hertha, (2017) musik adalah salah satu hal yang menyenangkan dikarenakan musik dapat membuat otak menghasilkan dopamin saat mendengarkannya.

Dari studi literatur yang peneliti lakukan pada jurnal dan buku-buku ada sebuah fenomena bahwa seni musik khususnya lirik pada lagu dapat meningkatkan komunikasi verbal pada anak autistik sehingga peneliti tertatik untuk membuktikan apakah lirik pada lagu dapat meningkatkan komunikasi verbal pada anak autistik khususnya di sekolah Bina Anggita Yogyakarta. Tujuan dari penelitian ini adalah untuk mengetahui peran lirik dalam lagu untuk meningkatkan kemampuan komunikasi pada anak autistik di sekolah Bina Anggita Yogyakarta.

\section{Metode}

Prosedur pelaksanaan suatu penelitian harus didasari dengan metode penelitian ilmiah agar hasil yang diperoleh dapat dipertanggungjawabkan kebenarannya. Dalam penelitian ini menggunakan metode kualitatif. Penelitian kualitatif merupakan metode-metode untuk mengeksplorasi dan memahami makna yang oleh sejumlah individu atau sekelompok orang dianggap berasal dari masalah sosial atau kemanusiaan (Creswell, 2016:4). Dalam penelitian kualitatif metode yang biasanya dimanfaatkan adalah wawancara, pengamatan, dan pemanfaatan dokumen. Penelitian ini menggunakan metode kualitatif dengan pendekatan studi kasus, dikarenakan peneliti meneliti langsung pada objek penelitian dalam mengungkapkan peran lirik dalam lagu untuk meningkatkan komunikasi verbal pada anak autistik di sekolah Bina Anggita Yogyakarta. Studi kasus merupakan rancangan penelitian di mana peneliti mengembangkan analisis mendalam pada suatu kasus, seringkali program, peristiwa, aktivitas, proses, atau satu individu atau lebih. Kasus-kasus dibatasi oleh waktu dan aktivitas, dan peneliti mengumpulkan informasi secara 
lengkap dengan berbagai prosedur (Creswell, 2016).

Selain pendekatan studi kasus penelitian ini menggunakan pendekatan penelitian studi pustaka juga, dikarenakan untuk mengumpulkan informasi dari jurnaljurnal dan buku-buku untuk mendukung penelitian ini. Studi kepustaka adalah kegiatan untuk menghimpun informasi yang relevan dengan topik atau masalah yang menjadi obyek penelitian. Informasi tersebut dapat diperoleh dari buku-buku, karya ilmiah, tesis, disertasi, ensiklopedia, internet, dan sumber-sumber lain. Dengan melakukan studi kepustakaan, peneliti dapat memanfaatkan semua informasi dan pemikiran-pemikiran yang relevan dengan penelitiannya. Secara Umum Studi pustaka adalah cara untuk menyelesaikan persoalan dengan menelusuri sumber-sumber tulisan yang pernah dibuat sebelumnya. Tujuan pertama melakukan studi pustaka ialah menemukan variable-variabel yang akan diteliti. Pada praktiknya, peneliti sering mengalami kesulitan untuk merumuskan masalah yang layak untuk diteliti. Masalah yang diteliti pada hakekatnya merupakan variable-variabel yang akan diteliti. Disamping membantu mengidentifikasi masalah yang akan diteliti, studi pustaka juga dapat membantu peneliti dalam mendefinisikan variable baik secara konseptual ataupun secara operasional dan yang lebih penting ialah membantu dalam mengidentifikasi adanya hubungan antar variable yang secara konseptual atupun operasional penting untuk diteliti.

Tujuan kedua ialah membedakan halhal yang sudah dilakukan dan menentukan hal-hal yang perlu dilakukan agar tidak terjadi duplikasi penelitian atau karya di masa lalu yang sudah pernah dilakukan oleh orang lain. Perlu diketahui juga bahwa penelitian masa lalu dapat menjadi bahan atau setidak-tidaknya memberikan gagasan atau inspirasi terhadap penelitian yang akan dilakukan saat ini, khususnya penemuan- penemuan sebelumnya dapat memberikan arahan kepada kita dalam melakukan penelitian saat ini. Kita sering mendapatkan banyak hasil penelitian di masa lalu menyarankan untuk dilakukan penelitian lebih lanjut / mendalam mengenai topik yang sudah diteliti.

Tujuan yang ketiga ialah melakukan sintesa dan memperoleh perspektif baru, maksudnya jika seorang peneliti dengan cermat dapat melakukan sintesa hasil hasil penelitian sejenis di masa lalu, maka ada kemungkinan peneliti tersebut menemukan sesuatu yang penting mengenai gejala yang sedang dipertanyakan dan cara-cara bagaimana mengaplikasikan kedalam konteks penelitian saat ini. Pada umunya para peneliti lebih memilih hal-hal yang bersifat spesifik daripada hal-hal yang bersifat umum.

Tujuan keempat ialah menentukan makna dan hubungan antar variable karena semua variable yang diteliti harus diberi nama, didefinisikan dan disatukan dengan masalah yang sudah dirumuskan beserta hipotesanya. Jika seseorang melakukan proses mendefenisikan variable dengan tanpa melakukan studi kepustakaan terlebih dahulu maka kemungkinan yang akan diperoleh ialah kesalahan dalam pendefenisian variabel. Dengan melakukan studi kepustakaan, peneliti yang bersangkutan akan mendapatkan tuntunan secara teori cara-cara mendefenisikan suatu variable dan juga kemungkinankemungkinan adanya variable yang secara konseptual sudah didefinisikan oleh peneliti sebelumnya. Khususnya dalam ilmu-ilmu social dan psikologi, pada umumnya gejala atau variable sudah didefinisikan secara konseptual dan operasional dalam bukubuku teori yang ada (http:// jsarwono.psend.com/ bab6.html).

Teknik Pengumpulan Data

Sebelum peneliti terjun langsung untuk observasi objek penelitian, peneliti 
melakukan studi pustaka terlebih dahulu teknik pengumpulan data studi pustaka yang digunakan dalam penelitian ini antara lain:

a. Compare: compare adalah mencari kesamaan dari penelitian yang kita lakukan dengan literatur seperti jurnal dan buku-buku.

b. Contrast: contrast yaitu mencari ketidaksamaan antara penelitian yang akan dilakukan dengan literatur yang ada.

c. Criticize yaitu memberikan pandangan terhadap literatur-literatur yang menjadi bahan penelitian.

d. Synthesize yaitu membandingkan literatur-literatur yang dimana literatur tersebut akan mendukung penelitian yang akan dilakukan.

e. Summarize yaitu meringkas literaturliteratur yang menjadi bahan penelitian.

Setelah peneliti melakukan studi pustaka peneliti terjun langsung dalam observasi ke sekolah Bina Anggita. Observasi awal dalam penelitian ini dilakukan selama dua minggu sebelum dilakukan perlakuan. Observasi dilakukan Sekolah Bina Anggita. Tujuan dilakukannya obsevasi awal ialah untuk membantu peneliti dalam menyusun asesmen, serta memperkenalkan diri dan belajar berinteraksi secara langsung dengan subjek peneliti. Hal ini mengingat kondisi anak penyandang autistik memiliki kecenderungan sulit didekati dan menerima orang baru. Diharapkan juga melalui obserasi ini akan terjalin kerjasama yang baik, tidak hanya antar peneliti dan subjek, tetapi juga dengan semua anggota msyarakat di lingkungan sekolah. Menurut Creswell (2016:254) observasi adalah ketika peneliti langsung turun ke lapangan untuk mengamati perilaku dan aktivitas individuindividu di lokasi penelitian. Dalam penelitian ini peneliti merekam/mencatatbaik dengan cara terstruktur maupun semistruktur aktivitas-aktivitas di lokasi penelitian. Peneliti memilih jenis observasi partisipasi pasif, dalam observasi pastisipasi pasif ini peneliti datang di tempat berlangsungnya kegiatan subjek yang diamati, tetapi tidak ikut terlibat dalam kegiatan tersebut.. Dalam kegiatan observasi ini peneliti melakukan pengamatan langsung terhadap subjek penelitian, yaitu dengan mengamati perkembangan verbal anak autistik selama diterapkan bernyanyi dengan menggunakan lirik.

Prosedur Penelitian

Dalam penelitian ini peneliti melakukan beberapa prosedur tahapan dan langkah-langkah agar data yang terkumpul dapat terstruktur dengan baik, langkahlangkah tersebut adalah:

Langkah 1: Tahapan pra-lapangan

Pada tahap ini peneliti mengadakan persiapan penelitian yaitu menguraikan hasil siklus tahapan, mulai dari memilih lapangan penelitian, penyusunan pedoman observasi dan wawancara, mengurus perizinan, persiapan alat-alat penunjang penelitian, pemilihan lagu-lagu.

Langkah 2: Tahap Pekerjaan lapangan

Dalam tahapan ini peneliti melakukan studi pustaka terlebih dahulu sebelum melakukan observasi. Setelah itu observasi dilakukan untuk melihat dan meninjau tempat penelitian serta obsevasi terhadap objek penelitian dan peneiti melakukan wawancara terhadap guru-guru dan orang tua objek penelitian.

Langkah 3: Tahapan Hasil Pengunpulan Data

Pada tahapan ini peneliti menganalisis data dan menarik kesimpulan dari data-data yang telah dikumpulkan dari lapangan.

\section{Pembahasan}

Berdasarkan hasil penelitian yang telah dilakukan peneliti dengan menggunakan studi pustaka dan observasi guna untuk mencari perkembangan bahasa verbal anak autistik di Sekolah Bina Anggita 
Yogyakarta melalui bernyanyi dengan lirik sederhana dalam sebuah lagu. Telah ditemukan bahwa meningkatnya bahasa verbal anak autistik saat diterapkannya pemblajaran musik dengan bernyanyi menggunakan lirik pada lagu anak-anak dengan lagu Pelangi-Pelangi dan Balonku. Sedikit demi sedikit lirik dalam lagu tersebut menstimulus anak autistik untuk mengikuti lirik lagu Balonku dan Pelangi-Pelangi, meskipun anak autistik hanya mampu mengikuti akhiran setiap kata pada kalimat dalam lirik-lirik lagu tersebut. Seperti contoh saat guru menyanyikan lagu Balonku.

\section{Penutup}

Dari pembahasan yang telah dijabarkan peneliti mengambil sebuah kesimpulan yaitu:

1. Peran lirik dalam lagu Balonku dan Pelangi-Pelangi memberikan dampak secara signifikan dalam meningkatkan komunikasi verbal anak autistik. Meskipun respons yang ditimbulkan anak autistik beragam namun tingkat keberhasilan dalam menstimulus anak autistik untuk berkomunikasi secara verbal sangat terlihat. Dari pembahasan di atas dapat dilihat bahwa lagu Balonku dan Pelangi-pelangi memiliki dampak yang cukup kuat dikarenakan artikulasi yaitu pengucapan kata-kata pada lirik lagu memiliki peran dalam meningkatkan kosa kata dan komunikasi verbal bagi anak autistik. Anak dapat mengikuti artikulasi dalam lirik lagu tersebut walaupun hanya sebagian saja, namun dapat membantu mengekspresikan respons emosi musikal yang dirasakan oleh anak autistik.

2. Selain lirik dalam lagu Balonku dan Pelangi-Pelangi fitur tempo menjadi salah satu faktor yang dapat mendukung anak autistik dalam meningkatkan bahasa verbal anak autistik, dikarenakan cepat-lambatnya tempo dapat mempengaruhi anak dalam mengikuti lirik dalam lagu tersebut. Jika tempo terlalu cepat anak autistik cenderung malas mengikutinya karena anak autistik butuh konsentrasi penuh untuk mengikutinya, sedangkan tempo lambat anak autistik dapat mengikutinya dikarenakan lebih mudah anak autistik untuk mengikutinya. Sehingga tempo juga mendukung dalam menstimulus anak untuk ikut bernyanyi bersama.

\section{Referensi}

Anggreani, Nurwinda. 2014. Kegiatan Bermain Musik Bagi Anak Autis di Taman Musik Dian Indonesia Cilandak Barat Jakarta Selatan. Bandung: Universitas Pendidikan Indonesia.

Ann Darrow, Alice And Tammy Armstrong. 1999. Research On Music And Autism Implications For Music Educarors. Department of Music and Dance University of Kansas, pp 16.

Asuncion, Annette. 2017. Music Therapy In Special Education, Music Therapy Centre Indonesia, Jakarta, 30 Maret1 April.

Creswell, John W. 2016. Research Design. Yogyakarta: Pustaka Pelajar.

Djohan. 2006. Terapi Musik, Teori dan Aplikasi. Yogyakarta: Galangpress.

Hertha, Saphira. 2017. Musik dan Perkembangan Anak Berkebutuhan Khusus, Music Therapy Centre Indonesia, Jakarta, 30 Maret-1April.

Kanner, Leo. 1971. Follow-up Study Of Eleven Autistic Children Originally Reported In 1943. Journal of Autism and Childhood Schizophrenia, 1-2, 119-145. 